\title{
宇宙機間の相対位置の制御について*
}

\author{
山田克 彦*1, 吉 河 章二*1, 西山岳宏*2
}

\section{On Relative Position Control between Two Spacecraft}

\author{
Katsuhiko YAMADA*3, Shoji YOSHIKAWA and Takehiro NISHIYAMA
}

*3 Advanced Research R \& D Center. Mitsubishi Electric Corporation.

8-1-1 Tsukaguchi-Honmachi. Amagasaki-shi. Hyogo, 661-8661 Japan

\begin{abstract}
Formation flight control of two spacecraft is considered in this paper. A trajectory of relative position change of one spacecraft with respect to the other is designed on the basis of the Hill's equation from the viewpoint of the minimum fuel consumption. The total fuel consumed along the trajectory is analytically obtained. Discrete two-degree-of-freedom control law is also proposed in order to realize the designed trajectory. The controller achieves deadbeat property of the closed loop system and guarantees the robustness to the controller gain decrease. Numerical studies are executed in order to verify the trajectory generation and the discrete control.
\end{abstract}

Key Words : Relative Motion Control, Hill's Equation, Fuel-Minimum Trajectory, Feedback Control

\section{1. まえがき}

2 機以上の宇宙機が相対的に位置を保ちながら運動 するフォーメーションフライトは, 近年観測ミッショ ンにおいてその重要性が注目されており,いくつかの プロジェクトが計画されている(1). しかし宇宙機が能 動的に制御を行わないで相対位置を保つためには，同 一軌道にあるか, レコード盤軌道のような特殊な相対 関係を持つ場合しか解がなく(2),一般的にはなんらか の制御を行う必要が生じる. 相対的な位置制御には推 薬を消費するので, ミッションを果たす場合のほかは, 例えば同一軌道にあって推薬を消費せずに相対関係を 維持し、ミッションのときだけ相対位置を変えること が考えられる．本報では，このように宇宙機が相対的 に位置を変える場合の制御則について検討したもので ある。このような宇宙機の相対的な位置変更は, 宇宙 開発事業団の技術試験衛星VII形で試みられており, 比 較的近傍域では直線的な軌道に沿って位置変更を行っ ている(3). また Tillerson らは宇宙機の相対運動を記

\footnotetext{
* 原稿受付 2003 年 9 月 15 日.

*1 正員, 三菱電機 (株) 先端技術総合研究所 (\$661-8661 尼崎 市塚口本町 8-1-1).

*2 三菱電機 (株) 先端技術総合研究所.

E-mail : Yamada.Katsuhiko@ wrc.melco.co.jp
}

述する方程式をもとに，推薬最小となる軌道をLP問 題の解として求めている(4). これに対して本報では, 円軌道運動を行う宇宙機が相対的に位置を変える場合 の運動軌道について, 推薬消費が $L_{2}$ ノルムの意味で 最小となる解を解析的に導出し, その性質について考 察した。さらにその軌道を実現するための宇宙機の制 御方法について検討を行った。ここで述べる方法は, 軌道離心率や地球重力場の不均一性の影響を考慮して いない点において基礎的な段階のものであるが, 比較 的簡単な形で位置変更軌道や軌道に対する制御則が得 られるため, 宇宙機の相対位置制御における一つの典 型的な方法を提供するものと考えられる.

\section{Hill 方程式}

宇宙機の相対運動を記述する運動方程式として Hill 方程式を用いる(5). すなわちターゲット衛星が円 軌道運動をするものとし, ターゲット衛星の質量中心 位置を原点とする軌道座標系 $(x$ 方向をターゲット衛 星の進行方向に, $z$ 方向を地心方向にとる)において チェイサ衛星の質量中心位置を $\left(\begin{array}{lll}x & y & z\end{array}\right)$ とするとき, $x, y, z$ は次式に従うものとする.

$$
\begin{aligned}
& \ddot{x}-2 \omega \dot{z}=f_{x} \\
& \ddot{y}+\omega^{2} y=f_{y}
\end{aligned}
$$


$\ddot{z}+2 \omega \dot{x}-3 \omega^{2} z=f_{z}$

ただし $\omega$ はターゲットの軌道角速度, $f_{x}, f_{y}, f_{z}$ はチ エイサの単位質量当たりに働く力である.この力が働 かない場合の, 運動方程式の任意の初期条件に対する 解は次のように表される (Clohessy-Wiltshire 解).

$$
\begin{aligned}
& {\left[\begin{array}{c}
\boldsymbol{x}(t) \\
\dot{\boldsymbol{x}}(t)
\end{array}\right]=\left[\begin{array}{ll}
\Phi_{r r}(t) & \Phi_{r v}(t) \\
\Phi_{v r}(t) & \Phi_{v v}(t)
\end{array}\right]\left[\begin{array}{c}
\boldsymbol{x}(0) \\
\dot{\boldsymbol{x}}(0)
\end{array}\right]} \\
& \boldsymbol{x}=\left[\begin{array}{lll}
x & y & z
\end{array}\right]^{T}, \quad \dot{\boldsymbol{x}}=\left[\begin{array}{lll}
\dot{x} & \dot{y} & \dot{z}
\end{array}\right]^{T} \\
& \Phi_{r r}(t)=\left[\begin{array}{ccc}
1 & 0 & 6(\omega t-\sin (\omega t)) \\
0 & \cos (\omega t) & 0 \\
0 & 0 & 4-3 \cos (\omega t)
\end{array}\right] \\
& \Phi_{r v}(t)= \\
& {\left[\begin{array}{ccc}
-\frac{3 \omega t-4 \sin (\omega t)}{\omega} & 0 & \frac{2(1-\cos (\omega t))}{\omega} \\
0 & \frac{\sin (\omega t)}{\omega} & 0 \\
-\frac{2(1-\cos (\omega t))}{\omega} & 0 & \frac{\sin (\omega t)}{\omega}
\end{array}\right]} \\
& \Phi_{v r}(t)=\left[\begin{array}{ccc}
0 & 0 & 6 \omega(1-\cos (\omega t)) \\
0 & -\omega \sin (\omega t) & 0 \\
0 & 0 & 3 \omega \sin (\omega t)
\end{array}\right] \\
& \Phi_{v v}(t)=\left[\begin{array}{ccc}
-3+4 \cos (\omega t) & 0 & 2 \sin (\omega t) \\
0 & \cos (\omega t) & 0 \\
-2 \sin (\omega t) & 0 & \cos (\omega t)
\end{array}\right]
\end{aligned}
$$

さらに $\Phi_{r r}(t), \Phi_{r v}(t), \Phi_{v r}(t), \Phi_{v v}(t)$ に対して次の ように記号を定義する。

$$
\begin{aligned}
& \Phi(t)=\left[\begin{array}{ll}
\Phi_{r r}(t) & \Phi_{r v}(t) \\
\Phi_{v r}(t) & \Phi_{v v}(t)
\end{array}\right] \\
& \Phi_{r}(t)=\left[\begin{array}{l}
\Phi_{r r}(t) \\
\Phi_{v r}(t)
\end{array}\right], \quad \Phi_{v}(t)=\left[\begin{array}{l}
\Phi_{r v}(t) \\
\Phi_{v v}(t)
\end{array}\right]
\end{aligned}
$$

\section{3. 最終状態を満たす解}

$3 \cdot 1$ 推薬消費量を抑える準最適解 いまチエイ サ衛星に対する制御力を

$$
\boldsymbol{f}=\left[\begin{array}{lll}
f_{x} & f_{y} & f_{z}
\end{array}\right]^{T}
$$

として,これは時刻 $t=\tau_{i}(i=1,2, \cdots, N)$ において大 きさ $\boldsymbol{f}_{i}$ のインパルスカとして与えられるものとする. すなわち

$$
\boldsymbol{f}=\sum_{i=1}^{N} \boldsymbol{f}_{i} \delta\left(t-\tau_{i}\right)
$$

式 (3)を式 ( 2 )に代入して解を求めると, $t=T$ にお ける状態 $x(T), \dot{x}(T)$ は次のように表すことができ る.

$$
\begin{aligned}
& \boldsymbol{X}(T)=\Phi(T) \boldsymbol{X}(0)+\sum_{i=1}^{N} \Phi_{v}\left(T-\tau_{i}\right) \boldsymbol{f}_{i}, \\
& \boldsymbol{X}(t)=\left[\begin{array}{c}
\boldsymbol{x}(t) \\
\dot{\boldsymbol{x}}(t)
\end{array}\right] \ldots \ldots \ldots \ldots \ldots \ldots \ldots \ldots \ldots \ldots \ldots \ldots \ldots \ldots \ldots \ldots \ldots
\end{aligned}
$$

ただし $T \geq \tau_{i}$ とする.ここで $\boldsymbol{X}(T)$ を望ましい值に するように制御力 $\boldsymbol{f}_{i}$ を求める問題を考えよう. 次の ように記号を定義する。

$$
\begin{aligned}
& \boldsymbol{\Phi}_{v}=\left[\begin{array}{lllll}
\Phi_{v}\left(T-\tau_{1}\right) & \Phi_{v}\left(T-\tau_{2}\right) & \cdots & \Phi_{v}\left(T-\tau_{N}\right)
\end{array}\right] \\
& \boldsymbol{F}=\left[\begin{array}{llll}
\boldsymbol{f}_{1}^{T} & \boldsymbol{f}_{2}^{T} & \cdots & \boldsymbol{f}_{N}^{T}
\end{array}\right]^{T} \\
& \tilde{\boldsymbol{X}}(T)=\boldsymbol{X}(T)-\Phi(T) \boldsymbol{X}(0)
\end{aligned}
$$

ここで $N$ 回のインパルスに対して $\boldsymbol{\Phi}_{v}$ は $6 \times 3 N$ 次の マトリックス, $\boldsymbol{F}$ は $3 N$ 次のベクトルである.このと き式 (4) は次のように表すことができる.

$$
\boldsymbol{\Phi}_{v} \boldsymbol{F}=\tilde{\boldsymbol{X}}(T)
$$

もしも制御力 $\boldsymbol{F}$ とて $L_{2}$ ノルム(Euclidノルム) $\|\boldsymbol{F}\|_{2}$ を最小となる解を選ぶことにすると, $N \geq 2$ で $\boldsymbol{\Phi}_{v}$ がフルランクであるときに解は次の形で表され る.

$$
\boldsymbol{F}=\boldsymbol{\Phi}_{v}^{T}\left(\boldsymbol{\Phi}_{v} \boldsymbol{\Phi}_{v}^{T}\right)^{-1} \tilde{\boldsymbol{X}}(T)
$$

ただし $\|\boldsymbol{F}\|_{2}$ が最小であることは推薬最小であること を意味しない. $\boldsymbol{F}$ の第 $i$ 成分を $F_{i}(i=1, \cdots, 3 N)$ とす るとき,この各成分がスラスタによって独立に出力さ れるものとすれば, 推薬消費を直接的に表すのは $L_{1}$ ノルム $\|\boldsymbol{F}\|_{1}$ となる. $\|\boldsymbol{F}\|_{1}$ と $\|\boldsymbol{F}\|_{2}$ の定義式は次式で 表される.

$$
\begin{aligned}
& \|\boldsymbol{F}\|_{1}=\left|F_{1}\right|+\left|F_{2}\right|+\cdots+\left|F_{3 N}\right| \\
& \|\boldsymbol{F}\|_{2}=\sqrt{\left|F_{1}\right|^{2}+\left|F_{2}\right|^{2}+\cdots+\left|F_{3 N}\right|^{2}}
\end{aligned}
$$

ここで $\|\boldsymbol{F}\|_{1}$ と $\|\boldsymbol{F}\|_{2}$ との間には次の大小関係が成立 する.

$$
\|\boldsymbol{F}\|_{2} \leq\|\boldsymbol{F}\|_{1} \leq \sqrt{3 N}\|\boldsymbol{F}\|_{2}
$$

かりに $F_{i}$ が $\left[\begin{array}{ll}-1 & 1\end{array}\right]$ の間で一様分布するとすれば

$$
\|\boldsymbol{F}\|_{1} \approx \frac{3 N}{2}, \quad \sqrt{3 N}\|\boldsymbol{F}\|_{2} \approx \sqrt{3} N
$$

となるので $\sqrt{3 N}\|\boldsymbol{F}\|_{2}$ は $\|\boldsymbol{F}\|_{1}$ を推定する比較的よい 尺度となる。 またスラスタの向きが取付角度や衛星の 姿勢変動の影響で軌道座標系の各軸の方向を向いてい ないとすれば, $\|\boldsymbol{F}\|_{1}$ であっても推薬消費量を正確に 反映するわけではない。これらを考慮して,ここでは 解の求めやすい $\|\boldsymbol{F}\|_{2}$ を最小化する準最適解を用いる ことにする.この場合の $N$ 回のスラス夕噴射による 推薬消費量を次のようにおく.

$$
q_{N}=\sqrt{3 N}\|\boldsymbol{F}\|_{2}
$$

式 $(6)$ を用いれば時刻 $t=\tau_{i}$ における制御力 $\boldsymbol{f}_{i}$ は 次のように表すことができる.

$$
\boldsymbol{f}_{i}=\Phi_{v}^{T}\left(T-\tau_{i}\right)\left\{\left(\boldsymbol{\Phi}_{v} \boldsymbol{\Phi}_{v}^{T}\right)^{-1} \tilde{\boldsymbol{X}}(T)\right\}
$$

$\boldsymbol{f}_{i}$ にこの解を用いることにすれば，時刻 $t$ における状 態量 $\boldsymbol{X}(t)$ は次のように表すことができる.ただし $\tau_{i} \leq t$ を満たす最大の $i$ を $n$ とおく.

$$
\boldsymbol{X}(t)=\Phi(t) \boldsymbol{X}(0)
$$




$$
+\sum_{i=1}^{n} \Phi_{v}\left(t-\tau_{i}\right) \Phi_{v}^{T}\left(T-\tau_{i}\right)\left\{\left(\boldsymbol{\Phi}_{v} \boldsymbol{\Phi}_{v}^{T}\right)^{-1} \tilde{\boldsymbol{X}}(T)\right\}
$$

次に連続的に入力の与えられる場合に解を表すこと を考えよう、インパルスの与えられる時間間隔を各間 隔で等しく $\Delta \tau$ とおいて $\tau_{i}=(i-1) \Delta \tau$ とする.このと き上式において

$$
\boldsymbol{\Phi}_{v} \boldsymbol{\Phi}_{v}^{T}=\sum_{i=1}^{N} \Phi_{v}(T-(i-1) \Delta \tau) \Phi_{v}^{T}(T-(i-1) \Delta \tau)
$$

と表すことができる.ここで $\Delta \tau \rightarrow 0(N \rightarrow \infty)$ の極限を とって式(10)を連続化する。いま

$$
C(t, T)=\int_{0}^{t} \Phi_{v}(t-\tau) \Phi_{v}^{T}(T-\tau) d \tau
$$

とおくことにすれば式(10)は次のように表される.

$$
\boldsymbol{X}(t)=\Phi(t) \boldsymbol{X}(0)+\boldsymbol{C}(t, T) \boldsymbol{C}^{-1}(T, T) \tilde{\boldsymbol{X}}(T)
$$

ここで $\boldsymbol{C}(t, T)$ は形は複雑になるが解析的に求める ことができるので, 上式の解を各時刻ごとに求めるこ

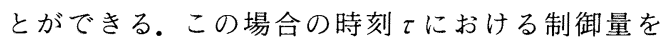
$\hat{\boldsymbol{f}}(\tau)$ とすると, $\hat{\boldsymbol{f}}(\tau)$ は次式で表される.

$$
\hat{\boldsymbol{f}}(\tau)=\Phi_{v}^{T}(T-\tau) \boldsymbol{C}^{-1}(T, T) \tilde{\boldsymbol{X}}(T)
$$

このときの推薬消費量は次のように求められる。 $N$ は時刻 $0 \sim T に お け る$ 噴射回数であるから, $N$ の大き なときには $N \approx T / \Delta \tau$ とみなされる。したがって離散 的に表現すれば

$$
\begin{aligned}
q_{N}^{2} & =\frac{3 T}{\Delta \tau} \sum \hat{\boldsymbol{f}}(\tau) \Delta \tau \cdot \hat{\boldsymbol{f}}(\tau) \Delta \tau \\
& =3 T \sum \hat{\boldsymbol{f}}(\tau) \cdot \hat{\boldsymbol{f}}(\tau) \Delta \tau
\end{aligned}
$$

よって $\Delta \tau \rightarrow 00$ の極限における推薬消費量を $q_{\infty}$ とおく と次式が成り立つ.

$$
q_{\infty}^{2}=3 T \int_{0}^{T} \hat{\boldsymbol{f}}(\tau) \cdot \hat{\boldsymbol{f}}(\tau) d \tau
$$

上式の右辺に式(13)を代入することによって $q_{\infty}$ は次 式となる。

$$
q_{\infty}=\sqrt{3 T \tilde{\boldsymbol{X}}(T)^{T} C^{-1}(T, T) \tilde{\boldsymbol{X}}(T)}
$$

$3 \cdot 2$ 準最適解の性質 式 (8)，(15)に基づいて 準最適解の性質について考察する。簡単のために次の 状況を対象とする.

$$
\begin{aligned}
& \boldsymbol{X}(0)=\left[\begin{array}{llllll}
x_{0} & 0 & 0 & 0 & 0 & 0
\end{array}\right]^{T} \\
& \boldsymbol{X}(T)=\left[\begin{array}{llllll}
x_{f} & y_{f} & z_{f} & 0 & 0 & 0
\end{array}\right]^{T}
\end{aligned}
$$

すなわち 2 機の宇宙機は, 初期時刻において同一軌道 にあって $x$ 方向にのみ距離が離れているものとし, 時

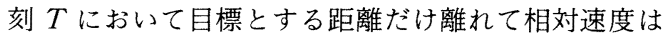
零になるものとする.このとき

$$
\Phi(T) \boldsymbol{X}(0)=\boldsymbol{X}(0)
$$

となることから, $\tilde{\boldsymbol{X}}(T)$ は次式となる.

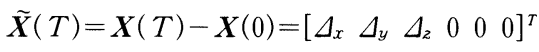

ただし $\Delta_{x}=x_{f}-x_{0}, \Delta_{y}=y_{f}, \Delta_{z}=z_{f}$ とする. $\tilde{\boldsymbol{X}}(T)$ は初期位置と目標位置の偏差分だけが值を持つ。

この状況で $N \rightarrow \infty$ の連続入力の準最適解における 式(15)の $q_{\infty}$ を求めることを考える. Hill 方程式にお いて $(x, z)$ 成分と $y$ 成分は分離されているので, $q_{\infty}$ における $y$ 成分の寄与項を $q_{\infty y}$ とおく， $q_{\infty y}$ は式(15) に基づいて計算することにより次式を満たす。

$$
q_{\infty y}^{2}=\frac{6 \omega^{3} T\{\omega T+\sin (\omega T) \cos (\omega T)\} \Delta_{y}^{2}}{\omega^{2} T^{2}-\sin ^{2}(\omega T)} \ldots
$$

$q_{\infty y}^{2}$ を $\omega T$ の関数とみなし, $\omega T$ で微分すると次式と なる.

$$
\frac{d\left(q_{\alpha}^{2}\right)}{d(\omega T)}=-\frac{12 \omega^{5} T^{3} \sin ^{2}(\omega T) \Delta_{y}^{2}}{\left\{\omega^{2} T^{2}-\sin ^{2}(\omega T)\right\}^{2}}
$$

したがって $q_{\infty y}$ は $\omega T$ に対して単調減少となるが, $\sin (\omega T)=0$ となる点の近傍では, その減少がゆるや かであることがわかる. 同様に $(x, z)$ 成分の影響に ついても求めることができるが, その関数形は $y$ 成分

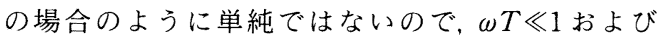
$\omega T \gg 1$ において近似的に表現する. 式(16)加求め られる $y$ 成分の結果もあわ゙せて示せば， $q_{\infty}$ はこれら の領域で次のように近似することができる.

$$
\begin{aligned}
& \omega T \ll 1: \\
& \left.q_{\infty} \approx \frac{6}{T} \sqrt{\Delta_{x}^{2}+\Delta_{y}^{2}+\Delta_{z}^{2}} \ldots \ldots \ldots \ldots \ldots \ldots \ldots \ldots . . . . . . . . . .18\right) \\
& \omega T \gg 1: \\
& q_{\infty} \approx \sqrt{\frac{4 \Delta_{x}^{2}}{T^{2}}-\frac{24 \omega \Delta_{x} \Delta_{z}}{T}+6\left(\omega \Delta_{y}\right)^{2}+58.8\left(\omega \Delta_{z}\right)^{2}}
\end{aligned}
$$

したがって $T$ が小さいときの推薬消費量はほほ $T$ に 反比例して隇少し， $T$ が大きくなると $\Delta_{y}, \Delta_{z}$ によっ てある一定值に漸近する。この場合, $\Delta_{z}$ による推薬 消費量は $\Delta_{x}$ や $\Delta_{y}$ による推薬消費量よりも大きくな ることがわかる.すなわち, 初期位置と目標位置に高 度差があると推薬消費量が大きくなる。

以上は連続入力の場合であるが, 次に $t=0, T$ の 2 回の噴射を行う $N=2$ の場合を考えよう。この場合解 は一意的なので最適性は持たないが,インパルス噴射 の最も単純な場合として比較の対象とする， $q_{2}$ にお ける $y$ 成分の寄与項を $q_{2}$ とおくと次式を満たす.

$$
q_{2 y}^{2}=\frac{6 \omega^{2}\left\{1+\cos ^{2}(\omega T)\right\} \Delta_{y}^{2}}{\sin ^{2}(\omega T)}
$$

$q_{2 y}^{2}$ を $\omega T$ で微分すると次式となる。

$$
\frac{d\left(q_{2 y}^{2}\right)}{d(\omega T)}=-\frac{24 \omega^{2} \cos (\omega T) \Delta_{y}^{2}}{\sin ^{3}(\omega T)}
$$

したがって $q_{2 y}^{2}$ は $\omega T=\{k+(1 / 2)\} \pi(k$ は非負の整 数)において極小值をとり, $\sin (\omega T)=0$ となる点にお いて発散する。これは式（5)のマトリックス $\boldsymbol{\Phi}_{v}$ が特 
異となるためである.また $(x, z)$ 成分は両者が干渉 して複雑になるが, $\Delta_{x}$ だけが存在する場合には, これ を比較的簡単に求めることができる． $q_{2}$ における $\Delta_{x}$ だけの寄与項を $q_{2 x}$ とすると次式が成り立つ.

$$
q_{2 x}^{2}=\frac{12 \omega^{2}\left\{1+3 \sin ^{2}\left(\frac{\omega T}{2}\right)\right\} \Delta_{x}^{2}}{\left\{8 \sin \left(\frac{\omega T}{2}\right)-3 \omega T \cos \left(\frac{\omega T}{2}\right)\right\}^{2}}
$$

これより $q_{2 x}$ は次式を満たす $\omega T$ においてやはり発 散する。

$$
\tan \left(\frac{\omega T}{2}\right)=\frac{3}{8} \omega T
$$

上式を満たす $\omega T(>0)$ の值は

$$
\omega T=8.84,15.36,21.75, \cdots
$$

となり, $\omega T=(2 k+3) \pi(k$ は非負の整数 $)$ よりやや小 さな值となる. 実際 $N=2$ の場合には式 $(5)$ において

$\operatorname{det} \boldsymbol{\Phi}_{v}=$

$$
-\frac{\sin (\omega T)\{3 \sin (\omega T) \omega T-8+8 \cos (\omega T)\}}{\omega^{3}}
$$

となり, $\sin (\omega T)=0$ および式(23)を満たす $\omega T$ にお いて det $\boldsymbol{\Phi}_{v}=0$ となって 2 回だけの噴射では制御で きない. $N=2$ において $z$ 成分の影響についても同様 に求め, $\omega T \ll 1$ の場合にこれを近似すると, $q_{2}$ は次 のようになる。

$$
\omega T \ll 1: q_{2} \approx \frac{2 \sqrt{3}}{T} \sqrt{\Delta_{x}^{2}+\Delta_{y}^{2}+\Delta_{z}^{2}}
$$

一方 $\omega T \gg 1$ の場合には $T$ の值によっては発散する が, $q_{2 y}$ が極小值をとる $\omega T=\{k+(1 / 2)\} \pi$ の場合に限 定すれば次式が得られる。

$$
\begin{aligned}
& \omega T=\left(k+\frac{1}{2}\right) \pi, \omega T \gg 1: \\
& q_{2} \approx \sqrt{\frac{20 \Delta_{x}^{2}}{3 T^{2}}-\frac{16 \omega \Delta_{x} \Delta_{z}}{T}+6\left(\omega \Delta_{y}\right)^{2}+30\left(\omega \Delta_{z}\right)^{2}}
\end{aligned}
$$

この結果より次のことがわかる. $\omega T \ll 1$ の場合には $N=2$ のほうが連続入力ょりも推薬量が少なくてす む. $\omega T \gg 1$ の場合には, $\omega T=\{k+(1 / 2)\} \pi$ ととるこ とによって, $\Delta_{z}$ の影響による推薬消費量は $N=2$ のほ

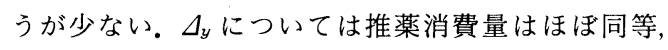
$\Delta_{x}$ については連続入力のほうが少なくなる.したが つて $N=2$ の場合でも推薬消費量の少なくなる場合が あるが, $N \rightarrow \infty$ ととることによって $T$ の值による推 薬消費量変化の少ない滑らかな軌道の得られる利点が ある.

なお $N=2$ の場合のほうが $N \rightarrow \infty$ の連続入力の場 合よりも推薬消費量が少なくなるのは, ここで求める 準最適解が $N$ を固定した場合の $\|\boldsymbol{F}\|_{2}$ を最小化する解
であるのに対して, 式 $(8)$ のように $\sqrt{3 N}$ を乗じて推 薬消費量 $q_{N}$ を求めているためである.

\section{4. 軌道に対するフィードバック制御}

$4 \cdot 1$ 軌道に対する離散的制御則 スラスタの推 力は不確定性が大きいので, チェイサ衛星の制御には フィードバック制御が必要となる。このとき各制御時 刻において目標時刻における制御誤差 $\tilde{\boldsymbol{X}}(T)$ を新た に計算し, 式 ( 9 )や式(13)から制御力を求めてもよい が,ここではより計算量の少ない, 与えられた軌道に 対するフィードバック制御を考えよう. 式(10)や式 (12)の解は時刻 $T$ における目標状態を実現する軌道 を表しているが，とくに軌道の種類を限定せずに，時 刻 $t$ における軌道を $\hat{\boldsymbol{X}}(t)$ とし, この軌道を実現する 制御力を $\hat{\boldsymbol{f}}(t)$ とする.この $\hat{\boldsymbol{f}}(t)$ として式 $(9)$ や式 (13) が候補となるが, これらに限定されるわけではな い. 実際の制御力は一定間隔 $\Delta \tau$ でインパルス的に与 えるものとし, 時刻 $t=\tau_{i}=(i-1) \Delta \tau$ における制御力 の大きさを $\boldsymbol{f}\left(\tau_{i}\right)$ とする. また各制御時刻において, チェイサ衛星の状態量 $\boldsymbol{X}(t)$ は検出されるものとす る. $\hat{\boldsymbol{X}}(t)$ と $\boldsymbol{X}(t)$ はそれぞれ次の方程式に従う.

$$
\begin{aligned}
& \hat{\boldsymbol{X}}(t)=\Phi(t) \hat{\boldsymbol{X}}(0)+\int_{0}^{t} \Phi_{v}(t-\tau) \hat{\boldsymbol{f}}(\tau) d \tau \\
& \boldsymbol{X}(t)=\Phi(t) \boldsymbol{X}(0)+\sum_{i=1}^{n} \Phi_{v}\left(t-\tau_{i}\right) \boldsymbol{f}\left(\tau_{i}\right) \cdots \cdots
\end{aligned}
$$

これより $\delta \boldsymbol{X}(t)=\hat{\boldsymbol{X}}(t)-\boldsymbol{X}(t)$ とすると,

$$
\begin{array}{r}
\delta \boldsymbol{X}(t)=\Phi(t) \delta \boldsymbol{X}(0)+\int_{0}^{t} \Phi_{v}(t-\tau) \hat{\boldsymbol{f}}(\tau) d \tau \\
-\sum_{i=1}^{n} \Phi_{v}\left(t-\tau_{i}\right) \boldsymbol{f}\left(\tau_{i}\right) \ldots \ldots \ldots \ldots \ldots \ldots \ldots \ldots \ldots \ldots \ldots \ldots \ldots \ldots
\end{array}
$$

この方程式において，ある制御力をインパルス的に加 える時刻を時刻零として, $\delta \boldsymbol{X}(t) \rightarrow \mathbf{0}$ とするような制 御力を与えることを考える. $\delta \boldsymbol{X}(t)$ は 6 次のベクトル なので1回のインパルスだけでは $\delta \boldsymbol{X}(t) \rightarrow \mathbf{0}$ を実現す ることはできない.ここでは $t=0, \Delta \tau$ の 2 回のイン パルスによって $\delta \boldsymbol{X}(2 \Delta \tau) \rightarrow \mathbf{0}$ とすることを考えると

$$
\begin{aligned}
& \delta \boldsymbol{X}(2 \Delta \tau)=\Phi(2 \Delta \tau) \delta \boldsymbol{X}(0) \\
& \quad+\int_{0}^{2 \Delta \tau} \Phi_{v}(2 \Delta \tau-\tau) \hat{\boldsymbol{f}}(\tau) d \tau \\
& \quad-\left[\begin{array}{ll}
\Phi_{v}(2 \Delta \tau) & \Phi_{v}(\Delta \tau)
\end{array}\right]\left[\begin{array}{c}
\boldsymbol{f}(0) \\
\boldsymbol{f}(\Delta \tau)
\end{array}\right]
\end{aligned}
$$

となることから, 制御力は次のように求められる。

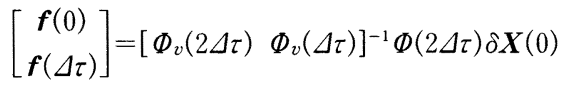

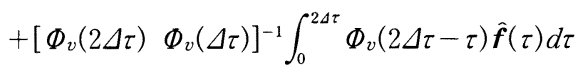

上式において右辺第 1 項はフィードバック制御項, 右 
辺第 2 項はフィードフォワード制御項となるが，この 場合は時刻零での制御誤差 $\delta \boldsymbol{X}(0)$ によって時刻 $\Delta \tau$ での制御力も定めることになるので, 時刻 $\Delta \tau$ での制 御誤差 $\delta \boldsymbol{X}(\Delta \tau)$ が反映されず, あまり望ましい形では ない.そこでフィードバック制御ゲイン $\boldsymbol{K} を$, $\delta \boldsymbol{X}(0)$ から $\boldsymbol{f}(0)$ を得るように次式で定めることを考 える.

$$
\begin{aligned}
\boldsymbol{K} & =\left[\begin{array}{ll}
\boldsymbol{I}_{3} & 0_{3 \times 3}
\end{array}\right]\left[\begin{array}{ll}
\Phi_{v}(2 \Delta \tau) & \Phi_{v}(\Delta \tau)
\end{array}\right]^{-1} \Phi(2 \Delta \tau) \\
& =\left[\begin{array}{ll}
\boldsymbol{I}_{3} & 0_{3 \times 3}
\end{array}\right]\left[\begin{array}{ll}
\Phi_{v}(\Delta \tau) & \Phi_{v}(0)
\end{array}\right]^{-1} \Phi(\Delta \tau) \cdots \cdots
\end{aligned}
$$

上式において $\boldsymbol{I}_{3}$ は 3 次の単位マトリックス, $0_{3 \times 3}$ は $3 \times 3$ 次の零マトリックスであり,

$\Phi_{v}(2 \Delta \tau)=\Phi(\Delta \tau) \Phi_{v}(\Delta \tau), \Phi_{v}(\Delta \tau)=\Phi(\Delta \tau) \Phi_{v}(0)$ などの関係を用いた. 式(32)において, $\boldsymbol{P}_{\mathbf{1}}, \boldsymbol{P}_{2}$ をとも に $6 \times 3$ 次のマトリックスとして

$$
\left[\begin{array}{l}
\boldsymbol{P}_{1} \\
\boldsymbol{P}_{2}
\end{array}\right]=\left[\begin{array}{ll}
\Phi_{v}(\Delta \tau) & \left.\Phi_{v}(0)\right]^{-1}
\end{array}\right.
$$

とおくことにすると, $\boldsymbol{P}_{1}, \boldsymbol{P}_{2}$ の定義から次式が成り立 ว.

$$
\begin{aligned}
& \boldsymbol{P}_{1} \Phi_{v}(\Delta \tau)=\boldsymbol{I}_{3}, \quad \boldsymbol{P}_{1} \Phi_{v}(0)=0_{3 \times 3} \\
& \boldsymbol{P}_{2} \Phi_{v}(\Delta \tau)=0_{3 \times 3}, \quad \boldsymbol{P}_{2} \Phi_{v}(0)=\boldsymbol{I}_{3} \\
& \Phi_{v}(\Delta \tau) \boldsymbol{P}_{1}+\Phi_{v}(0) \boldsymbol{P}_{2}=\boldsymbol{I}_{6} \ldots \ldots \ldots
\end{aligned}
$$

$\boldsymbol{P}_{1}$ を用いて $\boldsymbol{K}$ は次式となる。

$$
\boldsymbol{K}=\boldsymbol{P}_{1} \Phi(\Delta \tau)
$$

$\boldsymbol{K}$ を上式のように固定して, 時刻 $t=\tau_{i}$ における制御 力 $\boldsymbol{f}\left(\tau_{i}\right)$ を次のように与える.

$$
\boldsymbol{f}\left(\tau_{i}\right)=\boldsymbol{K} \delta \boldsymbol{X}\left(\tau_{i}\right)+\boldsymbol{P}_{1} \int_{0}^{\Delta \tau} \Phi_{v}(\Delta \tau-\tau) \hat{\boldsymbol{f}}\left(\tau_{i}+\tau\right) d \tau
$$

上式でも右辺第 1 項がフィードバック制御項であり, 右辺第 2 項がフィードフォワード制御項である。この フィードフォーワード制御項の積分範囲は式(31)とは 異なり $\Delta \tau$ にる。これは次のサンプリングにおける フィードバック制御項との干渉をさけるためである. $\Delta \tau$ が十分に小さければ, フィードフォワード項自体が 小さくなるので, フィードバック制御によってフィード フォワード項を補償することができ, フィードフォワー ド項を付加する必要はないものと考えられる.

$4 \cdot 2$ 制御則の安定性 式(37)の制御則が安定に なることは次のようにしてわかる.式(29)において $\Delta \tau$ ごとの離散的なふるまいを考えて, $\tau_{i}=(i-1) \Delta \tau$ とすると, $\Delta \tau$ 間における変動は次のように表すこと ができる.

$$
\begin{aligned}
& \delta \boldsymbol{X}\left(\tau_{i+1}\right)=\Phi(\Delta \tau) \delta \boldsymbol{X}\left(\tau_{i}\right) \\
& \quad+\int_{0}^{\Delta \tau} \Phi_{v}(\Delta \tau-\tau) \hat{\boldsymbol{f}}\left(\tau_{i}+\tau\right) d \tau-\Phi_{v}(\Delta \tau) \boldsymbol{f}\left(\tau_{i}\right)
\end{aligned}
$$

上式に式(37)を代入すると

$$
\begin{aligned}
& \delta \boldsymbol{X}\left(\tau_{i+1}\right)=\left\{\Phi(\Delta \tau)-\Phi_{v}(\Delta \tau) \boldsymbol{K}\right\} \delta \boldsymbol{X}\left(\tau_{i}\right) \\
& \quad+\left(\boldsymbol{I}_{6}-\Phi_{v}(\Delta \tau) \boldsymbol{P}_{1}\right) \int_{0}^{\Delta \tau} \Phi_{v}(\Delta \tau-\tau) \hat{\boldsymbol{f}}\left(\tau_{i}+\tau\right) d \tau
\end{aligned}
$$

この式において右辺第 2 項はフィードフォワード制御 項の残差分であり, マトリックスの零空間を $\mathcal{N}$, 值域 をRで表すと,

$$
\mathcal{N}\left(\boldsymbol{I}_{6}-\Phi_{v}(\Delta \tau) \boldsymbol{P}_{1}\right)=\mathscr{R}\left(\Phi_{v}(\Delta \tau) \boldsymbol{P}_{1}\right)=\mathscr{R}\left(\Phi_{v}(\Delta \tau)\right)
$$

となることから, 式(39)の積分項のうち $\Phi_{v}(\Delta \tau)$ の值 域に属する部分は零になる。逆に $\Phi_{v}(\Delta \tau)$ の值域に属 さない部分はフィードフォワード残差となって残るこ とになる。この残差分を零とするには, 式 $(9)$ のう に離散的な入力により軌道を決めて, その入力の夕イ ミングにおいて制御を行うようにすればよい.しかし この残差分があっても系の安定性には関係せず, 安定 性に寄与するのは $\left\{\Phi(\Delta \tau)-\Phi_{v}(\Delta \tau) \boldsymbol{K}\right\}$ の部分である. この項の固有值がすべて単位円内部であれば系は安定 となる。式 $(33) \sim(35)$ の関係を用いて 一 $\left.\Phi_{v}(\Delta \tau) \boldsymbol{K}\right\}$ を計算すると次のようになる.

$$
\begin{aligned}
& \Phi(\Delta \tau)-\Phi_{v}(\Delta \tau) \boldsymbol{K}=\Phi(\Delta \tau)-\Phi_{v}(\Delta \tau) \boldsymbol{P}_{1} \Phi(\Delta \tau) \\
& =\left\{\boldsymbol{I}_{6}-\Phi_{v}(\Delta \tau) \boldsymbol{P}_{1}\right\} \Phi(\Delta \tau)=\Phi_{v}(0) \boldsymbol{P}_{2} \Phi(\Delta \tau) \\
& =\left[\begin{array}{c}
0_{3 \times 3} \\
\boldsymbol{I}_{3}
\end{array}\right]\left[\boldsymbol{P}_{2} \Phi_{r}(\Delta \tau) 0_{3 \times 3}\right]=\left[\begin{array}{cc}
0_{3 \times 3} & 0_{3 \times 3} \\
\boldsymbol{P}_{2} \Phi_{r}(\Delta \tau) & 0_{3 \times 3}
\end{array}\right]
\end{aligned}
$$

これより次式が成り立つ.

$$
\left\{\Phi(\Delta \tau)-\Phi_{v}(\Delta \tau) \boldsymbol{K}\right\}^{2}=0_{6 \times 6}
$$

上式より $\boldsymbol{K}$ が有限整定ゲインとなっていることがわ かる.したがって $\left\{\Phi(\Delta \tau)-\Phi_{v}(\Delta \tau) \boldsymbol{K}\right\}$ の 6 個の固有 值はすべて零であり, 系は安定である.このことは式

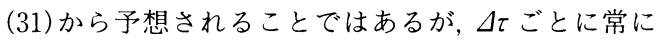
同じフィードバックゲインを用いて有限整定が達成さ れることになる。

次にフィードバックゲイン $\boldsymbol{K}$ の成分について考え よう. 式(33)，(36)より明らかなように $\boldsymbol{K}$ は次のよ うに表すことができる.

$$
\boldsymbol{K}=\left[\boldsymbol{P}_{1} \Phi_{r}(\Delta \tau) \boldsymbol{I}_{3}\right]
$$

したがってフィードバックゲイン $\boldsymbol{K}$ の速度偏差に対 応する部分は単位マトリックスとなる。このことは速 度偏差はその分だけインパルスカによって補償するこ とを意味している。一方，位置偏差に対するゲインは $\boldsymbol{P}_{1} \Phi_{r}(\Delta \tau)$ となる.この各成分は解析的に求めること ができるが，もしも $\omega \Delta \tau \ll 1 て ゙ あ り ，$

$\sin (\omega \Delta \tau) \approx \omega \Delta \tau, \cos (\omega \Delta \tau) \approx 1-\frac{1}{2}(\omega \Delta \tau)^{2}$ と近似できる場合には, $P_{1} \Phi_{r}(\Delta \tau)$ の各成分を次のよ 
うに簡単に表すことができる。

$$
\boldsymbol{P}_{1} \Phi_{r}(\Delta \tau) \approx\left[\begin{array}{ccc}
\frac{1}{\Delta \tau} & 0 & -\omega \\
0 & \frac{1}{\Delta \tau}\left\{1-\frac{1}{2}(\omega \Delta \tau)^{2}\right\} & 0 \\
\omega & 0 & \frac{1}{\Delta \tau}
\end{array}\right]
$$

したがって $\omega \Delta \tau$ が小さいときには位置偏差の $1 / \Delta \tau$ 程 度のインパルスカを必要とする.

$4 \cdot 3$ ゲイン低下に対するロバスト性スラスタ の推力には限界があるのでフィードバックゲイン $\boldsymbol{K}$ を式(42)よりも低めに設定せざるを得ない場合も考え られる.ここではこの場合の安定性について考えよ う. $\alpha$ を $0<\alpha \leq 1$ として閉ループ系におけるマトリ ックス

$$
\Phi(\Delta \tau)-\alpha \Phi_{v}(\Delta \tau) \boldsymbol{K}
$$

の 6 個の固有値を調べる.この特性方程式

$$
\operatorname{det}\left\{z \boldsymbol{I}_{6}-\left(\Phi(\Delta \tau)-\alpha \Phi_{v}(\Delta \tau) \boldsymbol{K}\right)\right\}=0
$$

を展開して整理すると固有値の二つは次式を満たすこ とがわかる。

$$
z^{2}-2(1-\alpha) \cos (\omega \Delta \tau) z+1-\alpha=0
$$

したがってこの固有值は次式で与えられる.

$$
\begin{aligned}
z & =(1-\alpha) \cos (\omega \Delta \tau) \\
& \pm j \sqrt{1-\alpha-(1-\alpha)^{2} \cos ^{2}(\omega \Delta \tau)}
\end{aligned}
$$

この場合 $|z|=\sqrt{1-\alpha}$ となるので, この固有值に関し

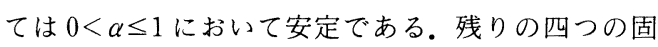
有值に関しては, $\omega \Delta \tau \ll 1$ の条件のもとで $(\omega \Delta \tau)^{3}$ 以上 の項を無視すれば, 次式を満たす 4 根となる.

$$
\begin{array}{r}
f(z)^{2}+(1-\alpha)(\omega \Delta \tau)^{2} z f(z) \\
-4(\omega \Delta \tau)^{2} \alpha(1-\alpha) z^{2}=0
\end{array}
$$

ただし $f(z)=z^{2}-2(1-\alpha) z+1-\alpha$ とおく.上式より $\omega \Delta \tau$ 分を捸動とみなして解を捸動的に求めることを 考える. 式 (47) を形式的に解いて高次の捸動項を無視 することにすると次式が得られる。

$$
f(z)= \pm 2 \omega \Delta \tau \sqrt{\alpha(1-\alpha) z}
$$

したがって

$$
z^{2}-2\{1-\alpha \pm \omega \Delta \tau \sqrt{\alpha(1-\alpha)}\} z+1-\alpha=0
$$

から得られる四つの根が求める固有值となる。これら を $z_{i}(i=1,2,3,4)$ とおくと, 次のようになる.

$$
\begin{aligned}
& z_{1,2}=1-\alpha+\omega \Delta \tau \sqrt{\alpha(1-\alpha)} \\
& \quad \pm j \sqrt{1-\alpha-(1-\alpha+\omega \Delta \tau \sqrt{\alpha(1-\alpha)})^{2}} \\
& z_{3,4}=1-\alpha-\omega \Delta \tau \sqrt{\alpha(1-\alpha)} \\
& \quad \pm j \sqrt{1-\alpha-(1-\alpha-\omega \Delta \tau \sqrt{\alpha(1-\alpha)})^{2}}
\end{aligned}
$$

ただし $\omega \Delta \tau$ は十分に小さく上式の根号内は正とする. すなわち

$$
\omega \Delta \tau \leq \sqrt{\frac{1}{\alpha}}-\sqrt{\frac{1-\alpha}{\alpha}}
$$

この場合にも各根において $|z|=\sqrt{1-\alpha}$ となるので, $\omega \Delta \tau \ll 1$ のもとでは $0<\alpha \leq 1$ における閉ループ極の絶 対値はすべて $\sqrt{1-\alpha}$ 程度となって, 安定であること がわかる.

4・4 準最適軌道に対する制御則 式(37)は一般 に目標状態までの時間軌道が与えられたときに, それ を実現する制御則を与えている。ここでは軌道が式 (12)の連続入力の準最適軌道である場合について, 具 体的な制御則を求める. 式 (37)の積分項に準最適軌道 における解を代入すると次式が得られる。

$$
\begin{aligned}
\int_{0}^{\Delta \tau} & \Phi_{v}(\Delta \tau-\tau) \hat{\boldsymbol{f}}\left(\tau_{i}+\tau\right) d \tau \\
& =\int_{0}^{\Delta \tau} \Phi_{v}(\Delta \tau-\tau) \Phi_{v}^{T}\left(T-\tau_{i}-\tau\right) d \tau \\
& \times \boldsymbol{C}^{-1}(T, T) \tilde{\boldsymbol{X}}(T) \\
& =\boldsymbol{C}\left(\Delta \tau, T-\tau_{i}\right) \boldsymbol{C}^{-1}(T, T) \tilde{\boldsymbol{X}}(T)
\end{aligned}
$$

これを式(37)に代入して準最適軌道に対する制御則が 次式で得られる。

$$
\begin{aligned}
& \boldsymbol{f}\left(\tau_{i}\right)=\boldsymbol{K} \delta \boldsymbol{X}\left(\tau_{i}\right) \\
& \quad+\boldsymbol{P}_{1} \boldsymbol{C}\left(\Delta \tau, T-\tau_{i}\right) \boldsymbol{C}^{-1}(T, T) \tilde{\boldsymbol{X}}(T)
\end{aligned}
$$

\section{5. 数 值 計 算 例}

$5 \cdot 1$ 準最適軌道の推薬消費量 まず式 $(10)$, (12)で表される準最適軌道の推薬消費量の到達時間 $T$ に対する関係を調べる. ターゲット衛星が円軌道 運動をするときの軌道角速度を $\omega=0.001[\mathrm{rad} / \mathrm{s}]$ と し, チェイサの初期值を

$$
\boldsymbol{x}(0)=\left[\begin{array}{lll}
0 & 0 & 0
\end{array}\right]^{T}, \quad \dot{\boldsymbol{x}}(0)=\left[\begin{array}{lll}
0 & 0 & 0
\end{array}\right]^{T}
$$

とする. 最終值を二つの場合について次のように定め て, 準最適軌道を求める.

Case 1: $\boldsymbol{x}(T)=\left[\begin{array}{lllll}1 & 000 & 1000 & 0\end{array}\right]^{T} \quad[\mathrm{~m}]$

$$
\dot{\boldsymbol{x}}(T)=\left[\begin{array}{lll}
0 & 0 & 0
\end{array}\right]^{T}
$$

Case 2: $\boldsymbol{x}(T)=\left[\begin{array}{llllll}1000 & 1000 & 1000\end{array}\right]^{T} \quad[\mathrm{~m}]$

$$
\dot{x}(T)=\left[\begin{array}{lll}
0 & 0 & 0
\end{array}\right]^{T}
$$

Case 1 と Case 2 の違いは目標值の $z$ 成分だけである が，z成分の有無によって式(19)，(26)に示したよう に推薬消費量は大きく影響を受けるので, 軌道も異な ったものとなることが予想される. 各 Caseにおいて, 目標位置に到達するまでの時間 $T$ を変化させて, $N$ $=\infty, 10,2$ の各場合について推薬消費量 $q_{\infty}, q_{10}, q_{2}$ お よび式(18), (19)に示される $q_{\infty}$ の近似值, 式(25), (26)に示される $q_{2}$ の近似值を求めて図 1,2 に示す. 


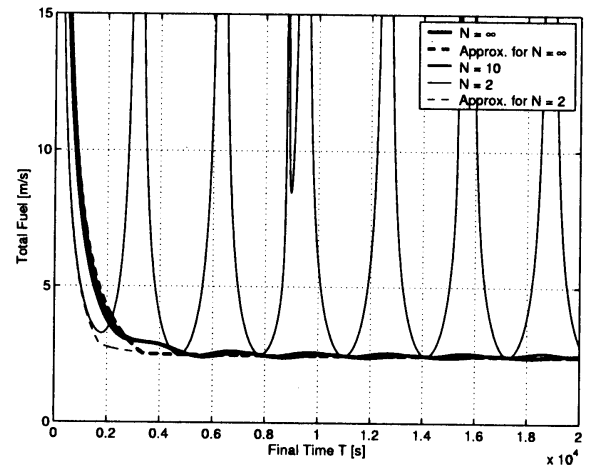

Fig. 1 Fuel consumption in Case 1

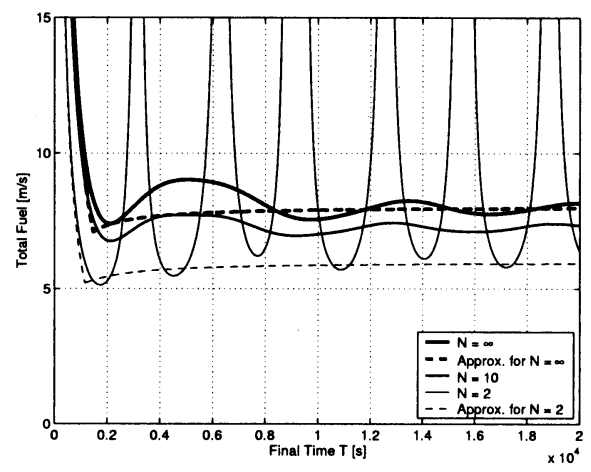

Fig. 2 Fuel consumption in Case 2

$q_{\infty}$ の近似値では式(18) と式(19)が交わる $T$ の值を $T_{c}$ として,$T \leq T_{c}$ では式(18)を， $T>T_{c}$ では式(19) を示す。 $q_{2}$ の近似值も同様である。図1, 2 より, $N$ $=2$ の場合には $\omega T=\{k+(1 / 2)\} \pi$ となる付近で推薬 消費量が極小値をとり，とくに $\Delta_{z}$ の存在する Case 2 では $N=10, \infty$ の場合よりも極小值付近において推薬 消費量が少なくなること, 式(18)，(19)は $q_{\infty} を$ 精度 よく近似し，式(25)，(26）は極小值付近での $q_{2}$ を精度 よく近似すること， $N=10$ の場合は $N=\infty$ の場合に 近づくことなどがわかる.

$\mathbf{5 \cdot 2}$ 準最適軌道の形状 次にCase 1 と Case 2 のそれぞれについて, 目標位置に到達するまでの時間 $T$ を変化させて, $x z$ 平面における軌道と, 軌道の $y$ 方向成分の時間に対する関係を求める. $N=\infty, 10,2$ の各場合について, $T$ を $\omega T=\pi / 2,3 \pi / 2$ にとったと きの結果を図 3,4 に示す.図 3 は $x z$ 平面内の軌道を 表し, 図 4 は $y$ 方向の軌道の時間に対する関係を表 す.これらの結果より次のことがわかる、目標位置が $z$ 成分を持たないCase 1 の場合, $x z$ 平面の軌道は初 期にほぼ $+z$ 方向の初速度をもって軌道高度をさげ, 軌道運動を利用して $+x$ 方向の移動を達成する。一

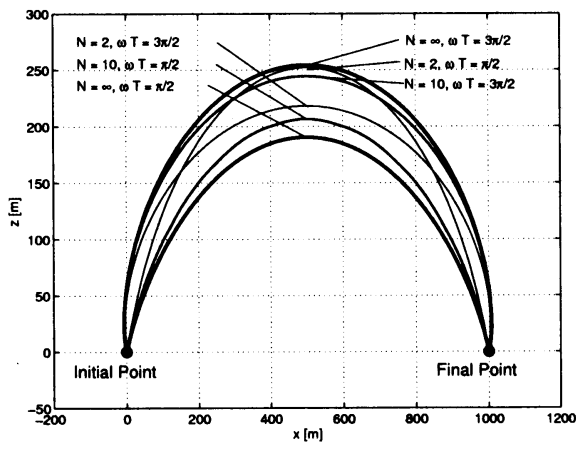

Case 1

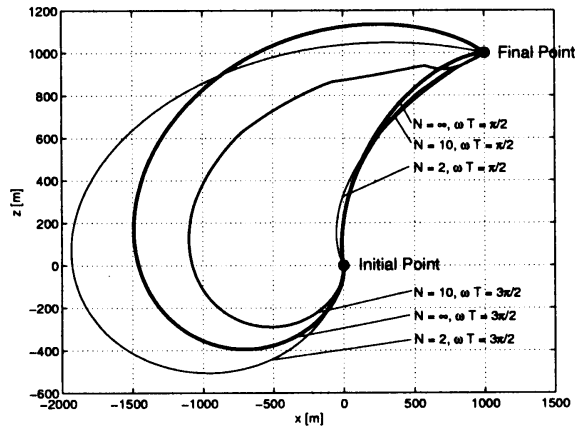

Case 2

Fig. 3 Trajectories in the $x z$-plane

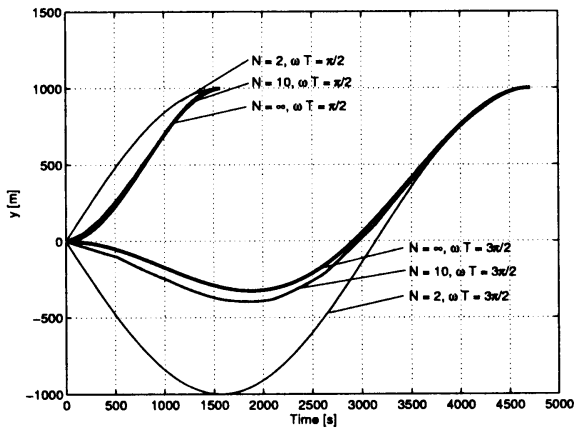

Fig. 4 Trajectories in the $y$-direction

方, 目標位置が $z$ 成分を持つ Case 2 の場合には, 時間 $T$ が短い場合 $(\omega T=\pi / 2)$ にはほぼ直線的な移動とな るが, 時間が長くなると $(\omega T=3 \pi / 2)$, ほぼーz方向 に初速度を与えてやはり軌道運動を利用して目標位置 にいたる， $y$ 方向の運動は Case 1 と Case 2 で同一で あり, 時間 $T$ が短いと時間に対して直線的な移動と なるが, 時間 $T$ が長くなると軌道運動を利用した正 弦波状の運動となる.

$5 \cdot 3$ 準最適軌道に対するフィードバック制御

次に式(12)の準最適軌道に対するフィードバック制 


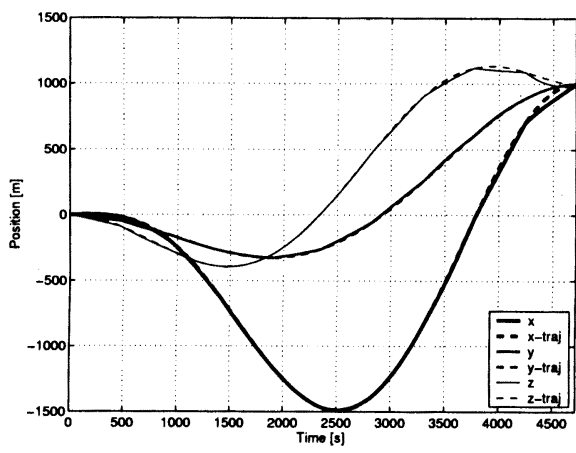

Time response of position control

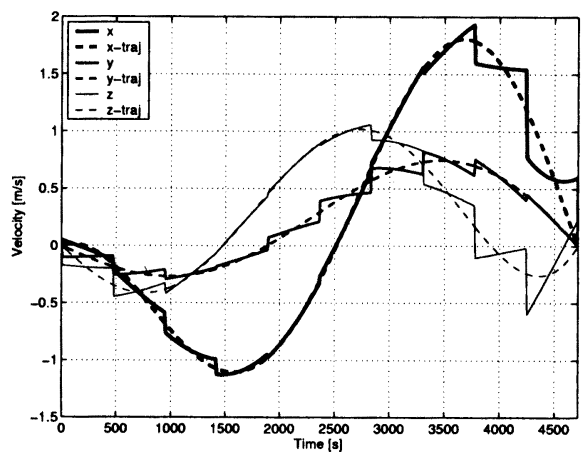

Time response of velocity control

Fig. 5 Simulation results of Case 2 (solid line: simulation, broken line : trajectory)

御の結果を示す. Case 2 の初期条件と最終条件のも とに到達時間 $T$ が $\omega T=3 \pi / 2$ を満たし, サンプリン グ時間が $\Delta \tau=T / 10$ のとの位置と速度のシミュレ ーション結果を図 5 に示す. 図 5 において実線が制御 結果, 破線が軌道を示す。図 5 より明らかなように位 置制御の結果はほとんど誤差を生じていない.サンプ リング時間が比較的長いためにサンプリング間での速 度誤差は生じているが, 準最適軌道に対する追従性は よい.

\section{6. ま と め}

本報では円軌道運動を行う 2 機の宇宙機がフォーメ ーションを組んでミッションを達成する場合を対象 に, 相対的に位置を変更するための軌道の構成法と, 位置変更軌道に沿うように宇宙機の制御を行うときの 制御法について検討を行った。軌道の構成法において は, Hill 方程式から推薬消費量を抑えることのできる 軌道の解を導き, その解を位置変更軌道の候補として, 同一軌道で進行方向に距離の離れた 2 機の宇宙機の, 一方が他方に対して相対的に位置を変更する場合の推 薬消費量を求めた。 また軌道の制御法においては, 制 御誤差を 2 回の制御において零に収束させることので きる有限整定のフィードバックゲインを求め, そのゲ インがゲイン低下に対してロバストであることを導い た.さらに相対位置変更時のシミュレーションを行 い, 制御のサンプリング間隔が長い場合にも制御誤差 を収束し得ることを確認した。本報で提案する方法 は, 2 機の宇宙機がフォーメーションを構成する際の 基本方式を提供するものと考えられる。

\section{文献}

(1) Bauer, F. H., Hartman, K., How, J. P., Bristow, J., Weidow. D. and Busse, F., Enabling Spacecraft Formation Flying through Spaceborne GPS and Enhanced Automation Technologies. Proccedings of the 12th International Technical Mecting of the Satellite Divi. sion of the Institute of Navigation, (1999), 369-383.

（2）中須賀真一, 宇宙機のフォーメーションフライト,システ 么/制御/情報, 45-10 (2001), 574-579.

（3）小山浩・功刀信・河野功・圭野正明, 自動ランデブ・ド ッキング実験の結果(航法誘導制御系の軌道上実証), 宇 宙開発事業団会議報告：ETS-VII「おりひめ」「ひこほ し」実験成果報告会前刷集, (2000-3)，66-72.

(4) Tillerson. M.. Inalhan, G. and How, J. P., Co-ordination and Control of Distributed Spacecraft Systems Using Convex Optimization Techniques, Int. J. Robust Nonlinear Control, 12 (2002), 207-242.

(5) Kaplan, M. H., Modem Spacecraft Dynamics \& Control. (1976), 109-115, John Wiley \& Sons. 